\title{
Desires and Rationality: A Psychoanalysis of Major Male Characters in The Hamlet
}

\author{
Mengyue $\mathrm{Cao}^{1}$ \\ ${ }^{1}$ Yangtze University College of Arts and Sciences, Jingzhou, China \\ Correspondence: Mengyue Cao, Department of Foreign Language, College of Arts and Sciences, Yangtze \\ University, Jingzhou, 434020, Hubei, China. E-mail: caomengyue915@aliyun.com
}

Received: May 18, 2015 Accepted: June 8, 2015 Online Published: August 31, 2015

doi:10.5539/ells.v5n3p129 URL: http://dx.doi.org/10.5539/ells.v5n3p129

\begin{abstract}
William Faulkner is one of the greatest modern writers in America. The Hamlet is a representative work among his later works, playing a very important role in his writing career. The paper is to analyze unconscious desires and conscious rationality of the major male characters in The Hamlet based on Freud's consciousness and unconsciousness theory. The three major male characters, Flem Snopes, Will Varner and Ratliff, have their own unconscious desires for social position, reputation or fortune. However, their desires are against morality and social customs in the Frenchman's Bend. Therefore, these desires are repressed into their unconsciousness. A sense of nervousness would appear in the unconsciousness due to the repression, and one must look for a way on the consciousness to release the sense. Their rationality could be considered the way of realizing their unconscious desires on the conscious level. Their rationality is seen in their language, actions or manners and so on. Therefore, the major male characters could be taken as combinations of unconscious desires and conscious rationality.
\end{abstract}

Keywords: The Hamlet, unconsciousness, consciousness, desire, rationality

\section{Introduction}

William Faulkner (1897-1962) is one of the greatest writers in modern America and a representative of American Southern writers. He created nineteen long novels and about one hundred short ones in his life time, and most of his works take Southern America as the setting and reflect the changes of Southern American society and the floating and sinking of status of every level in the society as well as the changes in spiritual life of Southern people in two hundred years. Among Faulkner's works, fifteen long novels and most short stories take place in Yoknapatawpha County, which is a fictional place whose archetype is Faulkner's hometown Lafayette. It is one of famous fictional places in the history of literature as well as a landmark of Faulkner's works. The Snopes Trilogy is a representative of his Yoknapatawpha novels.

The Snopes Trilogy is a very important work of Faulkner in the later period of his writing career. Moreover, it is the only trilogy Faulkner created in his lifetime and a work on which he spent the longest time. Early in the year of 1926, he had a rough idea and outline about the trilogy, but he finished it at last in the end of 1959 through decades' intermittent creation. The trilogy deeply reveals and criticizes the ruthlessness of business doctrine, and shows Faulkner's fear and worry that the traditional living way and values of Southern American society are changing and losing. Among the trilogy, The Hamlet is the one with the highest value.

The Hamlet (1940) is the first volume of the trilogy. It takes the Frenchman's Bend as the setting, telling a story about Flem Snopes. Flem Snopes is a person of unclear identity and an outsider in the Frenchman's Bend, and then becomes a clerk of Varner's store by using the chance that his father is driven out. Gradually, he takes charge of the accounts of the store and changes the way of running the store, and controls the business of the Blacksmith shop and the flower house, and gathers other family members to the Frenchman's Bend to help him obtain benefits. At last, Flem buries several bags of money in the Old Frenchman place to deceive Ratliff who is eager to get the treasure to buy the old house with a high price by making use of the legend that treasure is buried in the Old Frenchman place. After selling the house, Flem moves to Jefferson with money to develop his business.

Flem Snopes, Will Varner and Ratliff are three major characters in The Hamlet. They have their own desires for 
reputation, fortune or social status, and they all act in a rational way. Their desires belong to the unconscious level of psychological structure, while their rationality belongs to the conscious level. Their desires are the real drive of their rational behavior, and their rationality is the indirect way of realizing their unconscious desires. It could be inferred that the three major characters are combinations of conscious rationality and unconscious desires.

\section{Unconsciousness Theory in Freudian Psychoanalysis}

According to Freudian theory, desire is one of two important contents of the unconsciousness theory. It belongs to the unconscious level. Due to the constraint and the confinement of laws, morality, conscience and social customs, especially when these desires go against laws, morality, conscience and social customs, desires in spirit will be repressed into the unconscious, lying in the bottom part of man's psychological structure. Here, laws, social morality and customs are classified into the preconscious level, whose function is to remind, supervise and check the unconsciousness in order to prevent original instinctive impulse and desires from penetrating into the conscious which is the third level of man's psychological structure. The conscious and the unconscious are contrary mutually. The conscious represses the instinctive impulse of the unconscious, satisfying it deceptively and symbolically, while the unconscious is the basic drive of psychological activities, governing the conscious secretly. The unconscious is blind, chaotic but powerful and decisive, while the conscious is sober, rational but feeble.

The unconsciousness lies on the bottom level of psychological structure. Human's biological instinct and desires belong to the unconsciousness. Desires of Flem Snopes, Will Varner and Ratliff are on the unconscious level of their psychological structure.

In terms of Freudian theory of unconsciousness, man's psychological structure contains three levels, that is, unconsciousness, pre-consciousness and consciousness. The consciousness is the third level of one's psychological structure. It is the content that could be sensed directly, and is man's aimed and automatic psychological behavior which could be expressed in language and is controlled by social morality. The consciousness acts as the receptive section of inner unconscious stimulus, and mainly depends on such unconscious impulse as instinct and desires.

Desires belong to the unconsciousness. When desires are repressed into the unconsciousness, they will generate a sense of nervousness, and after experiencing supervision and check of the preconscious, desires will find a way out to release the sense and to pursue the satisfaction on the conscious level. As mentioned above, Flem, Varner and Ratliff have their own desires; however, these desires go against social morality in Old Frenchman's Bend, so they are repressed into the unconsciousness. Because of the existence of repression, the desire in the unconsciousness generates a sense of nervousness, and it will find some way to release the sense and to pursue the satisfaction and happiness. After desire experiences supervision and check of the preconscious on the second level of psychological structure, it will come into the receptive consciousness. Rationality of Flem Snopes, Will Varner and Ratliff belongs to the conscious level, and it could be seen as the way of realizing their unconscious desires. Their conscious rationality is embodied in their action, behavior, manner, language or facial expression.

To understand the unconsciousness theory well is the key to understanding the three major male characters in The Hamlet.

\section{Unconscious Desires and Conscious Rationality of Flem Snopes}

Flem has a strong desire for obtaining fortune and social status in Frenchman's Bend, and his desires for fortune and social status are confined on his unconscious level. In the first place, we should take a close look at his desires. He is an outsider in the Frenchman's Bend. His father's dialogue with Jody Varner tells the point.

... "Where you been farming?" Varner said.

"West" He did not speak shortly. ...

"You mean Texas?"

"No."

“I see. Just west of here. ..." (Joseph \& Noel, 1990, p. 736)

And sentences "I hear your father has had a little trouble once or twice with landlord" and "Trouble that might have been serious" (Joseph \& Noel, 1990, p. 749) in Chapter One of Book One give us a hint that his family is almost driven out of the village because of the gossip about fires his father set to his former employers' barns. It can be said that he and his family are the disadvantaged group in the village, so he often covers his real feelings or thinking and acts in a very rational way. He never tells people or even his close relatives what has happened or 
what he is going to do, and even he never does so when he is alone or in his dream. There is commentary of his villagers on Flem in Chapter One of Book Four that could be cited here as a proof.

..."And all he will know," a second said. "His own kin will be the last man in the world to find out anything about Flem Snopess' business."

"No," the first man said, "He wouldn't be that. The first man Flem would tell his business to would be the man that was left after the last man died. Flem Snopes dont even tell himself what he is up to. Not if he was lying in bed with himself in a empty house in the dark of the moon.”... (Joseph \& Noel, 1990, p. 991)

His eyes are always indiscernible, stagnant and cold, and when he speaks, there are no changes of facial expression on his face; he never makes any mistakes in calculating, and he marries Varner's daughter who has already been pregnant before marrying him. To trace the reason why he does so, the superficial one is that he acts in this way in order to exist and live in the village, but the deeper and more real one would be that he wants to get what is beyond his living and basic existence, that is, he has a strong desire for gaining fortune and social status. In Chapter Two of Book Two, a description exposes his desire.

In the next summer, her sixteen, she not only did not look at him, she never saw him again because he now lived in the same house, eating at the same table, using her brother's saddle horse to attend to his and her father's interminable business. (Joseph \& Noel, 1990, pp. 866-867)

This is the image of Flem in the eyes of Eula when she is going to marry him. The words show that Flem's marriage with Eula could bring him fortune and social position in the Frenchman's Bend. And fortune and social status are just desires of Flem. However, these desires are not reasonable due to Flem's poor family background and his unclear identity as an outsider, and they are not in accordance with social morality of the Frenchman's Bend. According to Freudian unconsciousness theory, when desires are against such factors as morality, conscience and social customs, these desires would be repressed into the deepest part of human's psychological part. Therefore, it could be said that Flem's desires for fortune and social position are unconscious.

Flem Snopes' rationality is an indirect satisfaction of his repressed unconscious desire on conscious level. His behavior, language and facial expression show his conscious rationality.

In the first place, Flem's behavior demonstrates his conscious rationality. Flem is the son of Ab Snopes who sets fire to the barn of De Spain after being subjected to his ravages and then rents a piece of land from Will Varner's son Jody, who attempts to drive him away just before the time of harvest after he worked hard in the field for a whole year. However, Flem makes good use of the chance that his father is cheated, and gets a job as a store clerk at the store set up by Will Varner. A dialogue could be quoted from Chapter One of Book One as a proof.

"Why, a good farm to work. Store credit. More land if he felt he could handle it."

"Aint no benefit in farming. I figure on getting out of it soon as I can."

...

"You run a store, don't you?" the other said.

“---better way---" Varner said. Then he stopped. "What?" he said.

"I hear you run a store." (Joseph \& Noel, 1990, p. 750)

It is just the first step for Flem to get into the upper society of Southern America. Flem's rationality in his behavior is also embodied in his marriage. Will Varner's daughter Eula is pregnant accidently and the father of the baby in her body is unknown, so Varner is eager to find a husband for her pregnant daughter in order to conceal the kind of family scandal and to protect fame of the family. At the time, Flem agrees to marry Eula, but his marriage with Eula is not for the sake of love at all, and he does this utterly because it would be beneficial to his ambition. It could be seen from Eula's attitude towards Flem in Chapter Two of Book Two as well.

...though sometimes she said Mr Snopes, saying it exactly as she would have said Mr Dog.

... she not only did not look at him, she never saw him again because he ... using her brother's saddle

horse to attend to his and her father's interminable business. (Joseph \& Noel, 1990, pp. 866-867)

From the above description, we see that obviously there is no love between Flem and Eula, and that Flem's marriage with Eula enhances his social status, so Flem's marriage is the result of his rationality.

Then, his conscious rationality is shown in his language. Language is said to be the tool of expressing one's thinking and mind. To understand one's thinking, we'd better have a look at his or her language. There is a 
conversation between Flem and Varner about Flem's father in Chapter One of Book One in the novel. It is cited as follows:

"I was hoping to see you," Varner said. "I hear your father has had a little trouble once or twice with landlord. Trouble that might have been serious." The other chewed. "Maybe they never treated him right; I dont know about that and I dont care. What I am talking about is a mistake, any mistake, can be straightened out so that a man can still stay friends with the fellow he aint satisfied with. Dont you agree to that?" The other chewed steadily. (Joseph \& Noel, 1990, p. 749)

Under the circumstance that his father is abused by others, he is not angry at all, but says he does not care about it and is thinking how to get a job by using the chance. His words cited above well show that Flem is a person who is good at controlling his emotion and making plans for his own future. And the kind of personality is a good proof of his rationality.

Furthermore, his conscious rationality could be seen in his facial expression as well. It is said that the eyes are the windows of the mind, so one's thinking and psychology are easily identified through his or her eyes. In The Hamlet, Faulkner makes detailed description of Flem's eyes many times throughout the whole novel. Some examples can be cited from Book One as a proof. The first one is as follows:

... He had a broad flat face. His eyes were the color of stagnant water. He was soft in appearance like Varner himself, though a head shorter, in a soiled white shirt and cheap gray trousers. (Joseph \& Noel, 1990, p. 749)

It is a piece of description of Flem Snopes' looking. William Faulkner uses "the color of stagnant water" to depict his eyes. The eyes of stagnant water reflect that Flem is a person with a stone heart. Usually, it is difficult for a stone-hearted person to be emotional rather than to be rational. Then in Chapter Two of Book One, there is another example:

Then he saw the eyes again, fierce and intractable and cold. "What's it to you if I do or dont?"

"Nothing," Ratliff said, pleasantly, quietly. Snopes stooped and hid the bottle in the weeds beside the

fence and returned to the plow and raised it. (Joseph \& Noel, 1990, p. 776)

When Ratliff offers him a bottle of water, the eyes of Flem is "fierce and intractable and cold". Through three adjectives, Faulkner displays well the complicated thinking process of mind and an indifferent attitude towards Ratliff's offer. The kind of complicated thinking and indifference is just the embodiment of Flem's rationality.

\section{Unconscious Desires and Conscious Rationality of Will Varner}

There is a desire for keeping his reputation and social status in the village in the heart of Will Varner, and his desire is constrained in his unconsciousness as well. Similarly, have a close look at Varner's desire at first. Will Varner enjoys high reputation and social status in the village.

Will Varner, the present owner of the Frenchman place, was the chief man of the country. He was the largest landholder and beat supervisor in one country and Justice of the Peace in the next and election commissioner in both, ... (Joseph \& Noel, 1990, p. 733)

He always talks important things in a careless way or avoids giving direct reply to others' words; he always looks at people with "the hard little eyes" (Joseph \& Noel, 1990, p. 752), but thinks about something else; he chooses Flem as the heir to his store and his bank other than his own son just because Flem is good at calculating. Reasons that he acts so should be traced back to his present status in the village. He is the owner of the land and the idol of village people, and what he does and how he acts are related to his reputation and his social status. For instance, Will Varner said to his son Jody who is angry after knowing that his sister Eula is pregnant: "Now you go on out to the barn and set down until you cool off. Make Sam dig you some worms and go fishing. If the family needs any head-holding-up done, I'll tend to it myself." (Joseph \& Noel, 1990, p. 864)

Here, the word "head-holding-up" tells us that what Varner will do regarding his pregnant daughter is to save the family's reputation and to keep his social position. But Varner's desire does not conform to villagers' expectations for him and morality of the village as the important man of the place. He should act for the interests of villagers in some sense. So considering Freudian viewpoint that desires will be repressed into consciousness when they go against laws, morality and conscience and so on, Varner's desire is also constrained on unconscious part of his psychological structure due to this inconsistency.

As for Will Varner's rationality, it is superficial expression of his unconscious desires for keeping reputation and social status in Frenchman place on the conscious level. Varner's action, conversation and facial expression demonstrate his conscious rationality. 
Firstly, Varner's conscious rationality is seen in two main actions. The first one is that he transfers some part of his wealth and power to Flem rather than his own son Jody. The reason is that Flem is one "who never made mistakes in any matter pertaining to money" (Joseph \& Noel, 1990, p. 782). According to common sense, the wealth and power of fathers are often passed down to their sons, and sons are the only heirs of families' fortune. However, Varner chooses a person who is not a member of his family rather than his son only because the former is more capable than the latter. The other one is in Varner's reaction after knowing the fact that his daughter is pregnant. When he gets to know that his daughter gets pregnant before getting married, his response is in a great contrast with Jody's. Jody is so angry that he "stood over her, shaking her arm and shouting: "Which one was it? Tell me which one!"' (Joseph \& Noel, 1990, p. 862), while Varner "came between them and thrust Jody back", and says "let her alone" (Joseph \& Noel, 1990, p. 862). Varner's way of coping with things calmly is a proof of his rationality.

Secondly, Varner's conversations with others show his conscious rationality. He often says his words according to the situation and never tells more information than necessary. For example, in Chapter Two of Book Two, there is a conversation between him and Ratliff:

"Evening, Uncle Will," he said in his pleasant, courteous, even deferent voice. "I hear you and Jody got a new clerk in the store." Varner looked at him sharply...

"So that's done spread," he said. "How far you have been since yesterday?"

"Seven-eight miles," Ratliff said.

"Hah," Varner said. "We've been need a clerk." That was true. All they needed was someone to come and unlock the store in the morning and lock it again at night—-this just to keep stray dogs out, since even tramps, like stray negroes, did not stay in Frenchman's Bend after nightfall. (Joseph \& Noel, 1990, p. 752)

From the conversation, we can see that before he responds to Ratliff's words, Varner makes clear how far the news has been spread first and then gives his reply. Moreover, when Ratliff says: "I hear you and Jody got a new clerk in the store", he just answers: "that we've been need a clerk". His answer is an indirect one, which not only helps to lessen Ratliff's curiosity and to make a good preparation for shifting the topic, but also shows Varner's calmness and rationality in face of enquiring. The following example also reveals Varner's shrewdness and rationality in his words. There is a dialogue between Ratliff and Varner in Chapter One of Book Three:

"You must have been desperate," he said quietly. He meant no insult. He was not even thinking of Varner's daughter's shame or of his daughter at all. He meant the land, the Old Frenchman place. He had never for one moment believed that it had no value. ...

Varner knew that Ratliff was thinking it. ... "So you think pure liver aint going to choke that cat," he said. (Joseph \& Noel, 1990, pp. 875-876)

Here Varner knows what Ratliff is thinking, but he just mentions an unimportant thing concerning the cat to shift the topic and avoid the point on which Ratliff intent to focus. It well embodies Varner's rational thinking.

Thirdly, Varner's facial expression also conveys his conscious rationality. In Chapter Two of Book One there is a small paragraph describing Varner's eyes:

"Evening, Uncle Will," he said in his pleasant, courteous, even deferent voice. "I hear you and Jody got a new clerk in the store." Varner looked at him sharply, the reddish eye-brows beetling a little above the hard little eyes. (Joseph \& Noel, 1990, p. 752)

Here, "sharply", "hard" and "little" are used to describe Varner's eyes, which not only shows that Varner understands the meaning of Ratliff's words, but also tells the readers that Varner is thinking how to give a reply to Ratliff's words. There are several other places where words like "hard" and "little" are used to describe Varner's eyes. For instance, in Chapter One of Book Three they are described as follows: He sat the old horse and looked down at Ratliff, the little hard eyes beneath their bushy rust-colored brows glinting at the man... (Joseph \& Noel, 1990, p. 876). In the sentence, words "down" and "glinting" more vividly reveal Varner's facial expression, and enrich the content of his eyes and psychology. Here is one more example in Chapter One of Book Four. The description is as follows:

... He glanced back at Ratliff for an instant, pausing. But the little hard bright eyes were invisible now; it was only the bushy overhang of the brows which seemed to concentrate downward toward him in written immobility, not frowning but with a sort of fierce risibility. (Joseph \& Noel, 1990, p. 1019)

It can be seen that words like "pausing", "bright" and "downward" are used here in addition to "little" and 
"hard". Repeatedly using these words to describe Varner's eyes well portrays his changeless facial expression. The emotion of a person is always presented in his or her face. If one is happy, his or her eyes would be bright and his or her face would be in an active state. On the contrary, if he or she is sad, his or her eyes would be grey and his or her face would be disappointed. If the change of facial expression is obvious, he or she can be said to belong to the emotional person, if not obvious, he or she should be classified into the group of the rational person. In The Hamlet, Varner belongs to the latter.

\section{Unconscious Desires and Conscious Rationality of Ratliff}

Ratliff harbors a desire for getting benefits and wealth, and the desire is repressed into unconscious part of his psychological structure. Ratliff is not aware of these desires, but they can affect his behavior. We will make clear Ratliff's desire before interpreting that his desire is unconscious. Ratliff is "an itinerant sewing-machine agent" (Joseph \& Noel, 1990, p. 734) and often goes miles in order to sell his machines. He is a mild person who keeps smiles on his face and is always polite to people around him, but actually he is competing with Flem in secret. The following thinking of Ratliff demonstrates the point.

... yes, he thought, if my name is Will Varner and my partner's name was Snopes I believe I would insist that some part of our partnership at least, that part of it that will burn anyway, would be in his name. ... (Joseph \& Noel, 1990, p. 797)

He is well-informed and is also keen on getting information and telling information about what has happened to people around the village. A clue could be seen from Varner's words in Chapter Two of Book One "So that's done spread," and "How far you have been since yesterday?" (Joseph \& Noel, 1990, p. 752).

He always talks in an indirect way, and his words need further understanding to catch the real meanings; he often bears a smooth and calm face and speaks in a low, pleasant and equable voice, and his tone is quite the same whatever situation he is in. Actually, this is just the masque of his desires for fortune. A paragraph in Chapter Two of Book Four could be cited here as an example. A little after six that evening, in the empty and locked store, Ratliff and Bookwright and Armstid bought the Old Frenchman place from Snopes. ... "It's ours now," Ratliff said. "And now we better get on out there and watch it before somebody fetches in Uncle Dick Bolivar some night and starts hunting buried money." (Joseph \& Noel, 1990, pp. 1063-1064)

It could be seen from the above words that Ratliff's buying the Old Frenchman place and digging treasure in the house in a hurry fully expose his desire for wealth. Nevertheless, to live or to act for benefits and fortune is not in line with people's definition of a respectable man. So it could be said that Ratliff's desire for benefits and wealth goes against social regulation in people's hearts, and it would naturally be repressed into the unconscious structure of Ratliff's psychology.

Ratliff's rationality is the indirect way of releasing nervousness of his unconsciousness and realizing his unconscious desires for wealth. His manner, language and facial expression tell his conscious rationality.

Above all, Ratliff's conscious rationality can be seen in his manners. Ratliff often speaks in a gentle and slow voice with the same tone no matter what occasion he is on, and he always smiles to people around him. Many proofs can be found from the novel text. For example, when Faulkner first introduces Ratliff into the novel in Chapter One of Book One, there is a piece of description of Ratliff when he is talking about the fires Snopes set to his former employers' barns.

He spoke in a pleasant, lazy, equable voice which you did not discern at once to be even more shrewd than humorous. This was Ratliff, the sewing-machine agent. ... (Joseph \& Noel, 1990, p. 740)

Here, words like "pleasant", "lazy" and "equable" well portray the gentleman image of Ratliff. Actually he is talking about a very serious thing, but he still speaks in a pleasant voice. In Chapter Three of Book One there is one more example:

... So that wasn't the last time this one is going to make his cousin trouble, he thought. But he did not say it, he just said, absolutely pleasant, easy, inscrutable: "I wonder where Uncle Will and his partner would be about now. I aint learned the route good yet like you folks.”(Joseph \& Noel, 1990, p. 816)

The example also shows that he is thinking in one way and speaking in another pleasant way, which emphasizes the contrast between Ratliff's inner mind and apparent acting.

Then, Ratliff's language embodies his conscious rationality as well. He is a typical gentleman of Southern America, so his words are always implicit and mild, and he seldom speaks out what he is really thinking in his mind at once. The way of conserving is a good embodiment of his rationality. Here are some proofs from the novel. In Chapter One of Book One, there is a conversation between Jody Varner and Ratliff about the fires 
Snopes set to the barns of his former employers.

"Hell, fire!" Varner cried. "Do you mean he set fire to another one? even after they caught him, he set fire to another one?"

"Well," the man in the buckboard said, "I dont know as I would go on record as saying he set ere a one of them afire. I would put it in that they both taken fire while he was more or less associated with them. You might say that fire seems to follow him around, like dogs follows some folks." (Joseph \& Noel, 1990, p. 740)

Facing Jody's question whether Snopes sets fires one after another, Ratliff does not give a positive answer, but just says: "you might say that fire seems to follow him around, like dogs follows some folks." The answer is quite shrewd and rational, because it expresses the same meaning with "Snopes set fires one after another", but Ratliff can also deny he once said "Snopes set fires one after another".

One more example could be found in Chapter Two of Book Four. When he goes together with Bookwright and Armstid digging treasures, he said: "If folks sees us, we might have too much help. That's what we want to dodge." (Joseph \& Noel, 1990, p. 1046) It can be easily understood that "If folks sees us, we might have too much help" is an ironic expression. The real meaning is that if somebody sees us, we will get into great trouble. Ratliff's rationality can be easily understood here.

Finally, Ratliff's facial expression shows his conscious rationality. Changes of facial expression of rational people are not obvious, and Ratliff could be classified into the rational kind. Here are some proofs from the novel text. In Chapter One of Book One, there is a piece of description of Ratliff's facial expression: ... But he was not laughing. The shrewd brown face was as bland and smooth as ever beneath the shrewd impenetrable eyes. (Joseph \& Noel, 1990, p. 742)

In the sentence, words such as "shrewd", "bland", smooth" and "impenetrable" are used to describe Ratliff's face and eyes. From these words, it can be seen that Ratliff does not show his real emotion, and his facial expression is rather calm in the situation that one should laugh out. One more example could be found in this chapter:

... Still he was not laughing. He just sat there in the buckboard, easy and relaxed, with his shrewd eyes in his smooth brown face, well-shaved and clean in his perfectly clean faded shirt, his voice pleasant and drawing and anecdotal, while Varner's suffused swollen face glared down at him. (Joseph \& Noel, 1990, p. 743)

Here, Ratliff still keeps his calmness, not laughing. And then his eyes are still shrewd and his face is still smooth, having no change on his face.

In conclusion, Flem Snopes, Will Varner and Ratliff play different roles and occupy different social positions in the village, but they have a common characteristic, that is, they are all rational people. Moreover, behind their rationality underlies their desires for wealth, reputation or social status, and their rationality could be taken as the indirect way of meeting their desires. Their rationality is on the conscious level, while their desires are on the unconscious level. Therefore, it could be concluded that the three major male characters are combinations of conscious rationality and unconscious desires.

\section{Conclusion}

William Faulkner is a great modern American writer. He wrote more than one hundred works in his life, and many of them are considered classical in literature. Most of his works could be ananlyzed under the theory of Faudian psychoanalysis.

The theory of consciousness and unconsciousness could be used to analyze the unconscious desires and the conscious rationality of the three major male characters. On the one hand, Flem Snopes, Will Varner and Ratliff have their own unconscious desires. Flem has a strong desire for fortune and social status; Will Varner's desire is to keep his reputation and social position; Ratliff's desire is to obtain wealth. But their desires are against social morality, so they are repressed into their unconscious level of psychological structure. On the other hand, the repression will generate a sense of nervousness, and the sense of nervousness needs to find a way into the conscious level. Flem, Varner and Ratliff's rationality is considered the way of fulfilling their unconscious desires on the conscious level. Their languages, actions or manners all convey their conscious rationality. Therefore, it could be said that the three main male characters in The Hamlet could be analyzed within the structure of Freud's theory of consciousness and unconsciousness. They could be considered combinations of conscious rationality and unconscious desires. 


\section{References}

Bai, X. H. (2004). The Philosophical Interpretation of Freud's Unconsciousness Theory. Shanghai: Fudan University.

Blotner, J., \& Polk, N. (Eds.). (1990). Faulkner novels 1936-1940. New York: The Library of America.

Elmore, O. (2007). Apophasis, Aletheia: William Faulkner's “The Hamlet” (pp. 71-82). New South Wales: Nebula.

Gao, C. X. (2006). The Snopes Trilogy-A Mirror of American South. Dalian: Dalian University of Foreign Languages.

Greet, T. Y. (1957). The Theme and Structure of Faulkner's “The Hamlet” (pp. 77-84). New York: PMLA.

Holmes, C. D. (1996). Annotations to William Faulkner's “The Hamlet”. New York \& London: Garland Publishing, Inc..

Ji, L. (2001). Studies of Faulkner in China. Jinan: Shandong Normal University.

Lei, H. Z. (2014). Faulkner Studies in America in the Perspective of Psychoanalysis (pp. 84-87). Xi’ an: Foreign Language Education.

Matthews, J. T. (2009). William Faulkner: Seeing through the South. Malden, MA: Wiley-Blackwell. http://dx.doi.org/10.1002/9781444306026

Pan, J. Y. (2009). Excessive rationality is Naked Madness-An Interpretation of Clegg in "The Collectors" (pp. 95-102). Nanjing: Comtemporay Foreign Literature.

Wang, W. F. (2004). The Lostness in "The Hamlet” (pp. 30-33). Chongqing: Journal of Sichuan International Studies University.

Weinstein, P. (2010). Becoming Faulkner, the Art and Life of William Faulkner. New York: Oxford University Press.

Xiao, M. H. (1997). Studies of William Faulkner. Beijing: Foreign Language Teaching and Research Press.

Zhu, Z. W. (2004). A Study of William Faulkner's Novel Creation from Perspective of Aesthestics. Shanghai: Xuelin Press.

\section{Copyrights}

Copyright for this article is retained by the author(s), with first publication rights granted to the journal.

This is an open-access article distributed under the terms and conditions of the Creative Commons Attribution license (http://creativecommons.org/licenses/by/3.0/). 